\title{
Tamsulosin-induced Hyperprolactinemia in a Patient with Multiple Sclerosis: A Case Report
}

\author{
Multipl Sklerozlu Bir Hastada Tamsulosine Bağlı Hiperprolaktinemi: Olgu Sunumu
}

\author{
(D) Ahmet Görgel1, (D) Ahmet Soylu1, (D) Sacit Görgel2, (1) Mehmet Tecellioğlu33, (D) Mehmet Sarıer 4,5 \\ 1 Gözde Academy Hospital, Clinic of Endocrinology, Malatya, Turkiye \\ ${ }^{2}$ Katip Çelebi University Faculty of Medicine, Department of Urology, İzmir, Turkiye \\ 3inönü University Faculty of Medicine, Department of Neurology, Malatya, Turkiye \\ 4 istinye University Faculty of Medicine, Department of Urology, Istanbul, Turkiye \\ 5 Medical Park Hospital, Clinic of Urology, İstanbul, Turkiye
}

\begin{abstract}
Drug-induced hyperprolactinemia is one of the most common causes of non-physiologic hyperprolactinemia. In contrary to other anterior pituitary hormones, prolactin is not controlled via hypothalamic-pituitary negative feedback mechanism. Since prolactin secretion is inhibited mainly by dopamine, some drugs such as antipsychotics and prokinetics which block dopamine receptors may lead to hyperprolactinemia. Nevertheless, despite this well-known phenomenon, most of cases of drug-induced hyperprolactinemia are asymptomatic. On the other hand, hyperprolactinemia due to tamsulosin that is an alpha adrenergic receptor antagonist has not been reported yet. Herein, we present a 39-year-old woman with multiple sclerosis who developed hyperprolactinemia after starting treatment with tamsulosin for neurogenic bladder disease.
\end{abstract}

Keywords: Drug-induced Hyperprolactinemia, Tamsulosin, Multiple Sclerosis

Öz

İlaca bağlı hiperprolaktinemi, fizyolojik olmayan hiperprolaktineminin en yaygın sebeplerinden biridir. Diğer ön hipofiz hormonlarının aksine prolaktin, hipotalamohipofizer negatif geri bildirim mekanizmasıyla kontrol edilmez. Prolaktin salgılanması başlıca dopamin tarafından engellendiği için, dopamin reseptörlerini bloke eden antipsikotikler ve prokinetikler gibi bazı ilaçlar hiperprolaktinemiye yol açabilir. Bununla birlikte, iyi bilinen bu fenomene rağmen ilaca bağlı hiperprolaktinemi olgularının çoğu semptomsuzdur. Diğer taraftan, bir alfa adrenerjik reseptör blokeri olan tamsulosine bağlı hiperprolaktinemi şimdiye kadar bildirilmemiştir. Bu yazıda nörojenik mesane hastalığı için tamsulosin tedavisi başlandıktan sonra hiperprolaktinemi tesbit edilen multipl sklerozlu 39 yaşındaki bir kadın olguyu sunuyoruz.

Anahtar Kelimeler: İlaca bağlı hiperprolaktinemi, Tamsulosin, Multipl sklerozis

\section{Introduction}

Hyperprolactinemia is one of the most frequently seen endocrine abnormalities. The prevalence of hyperprolactinemia ranges from $0.4 \%$ in an unselected adult population to as high as $9-17 \%$ in women of reproductive age (1). The primary action of prolactin is to promote lactation but it is the effect on the reproductive system that brings patients to clinical attention (2). In both sexes, hypersecretion of prolactin interferes with the pulsatile secretion of gonadotropin-releasing hormone, inhibits secretion of luteinizing hormone and follicle-stimulating hormone, and impairs gonadal steroid production leading to gonadal dysfunction and infertility. In women, galactorrhoea and menstrual irregularities occur due to prolactin excess. In men, hyperprolactinemia leads to decreased testosterone synthesis which clinically presents itself as erectile dysfunction and loss of libido.

The hypothalamic regulation of prolactin secretion unlike that of the other anterior pituitary hormones is predominantly

Correspondence: Ahmet Görgel MD, Gözde Academy Hospital, Clinic of Urology, Malatya, Turkiye

E-mail: gorgelahmet@yandex.com ORCID-ID: orcid.org/0000-0002-7766-9525

Received: 1.12.2018 Accepted: 25.02.2018

Cite this article as: Görgel A, Soylu A, Görgel S, Tecellioğlu M, Sarıer M. Tamsulosin-induced Hyperprolactinemia in a Patient with Multiple Sclerosis: A Case Report. J Urol Surg 2019;6(2):156-158.

- Copyright 2019 by the Association of Urological Surgery / Journal of Urological Surgery published by Galenos Publishing House. 
inhibitory, and dopamine is the most important inhibitory factor. Dopamine which is released from the hypothalamus reaches the anterior pituitary via the hypothalamic-pituitaryportal system and inhibits prolactin secretion. Certain physiologic conditions such as pregnancy, breastfeeding, nipple stimulation, neonatal period, exercise, stress, and sleep lead to increase in the level of serum prolactin. Lactotroph pituitary adenomas, also called prolactinomas, account for almost half of non-physiologic hyperprolactinemia. Other pituitary adenomas which not secrete prolactin may also cause hyperprolactinemia by compression of the pituitary stalk. Likewise, conditions affecting the hypothalamus such as granulomatous disorders, gliomas, craniopharyngiomas, metastases, trauma, and cranial irradiation may also cause prolactin elevation. Mild elevation of prolactin is seen in hypothyroidism due to the stimulatory effect of thyrotropin-releasing hormone on prolactin release. Hyperprolactinemia may also develop in some patients with liver cirrhosis or chronic renal failure owing to decreased hepatic and renal clearance, respectively.

Drugs affecting dopamine synthesis or release frequently lead to hyperprolactinemia. Drug-induced hyperprolactinemia is mostly asymptomatic and mainly occurs due to antipsychotics, tricyclic antidepressants, seratonin-reuptake inhibitors, monoamine oxidase inhibitors, some antihypertensives including methyldopa and verapamil, prokinetics such as metoclopropamide and domperidone. Tamsulosin is a highly selective alpha- 1 adrenergic receptor antagonist that is primarily used to treat the symptoms of prostatic hyperplasia in men. Alpha-1-receptors are involved in smooth muscle contraction and are abundant not only in the prostate but also in the prostatic urethra and bladder neck. Tamsulosin provides relaxation of smooth muscles in the bladder neck, therefore, its use may be beneficial to increase urine flow rate and to alleviate symptoms of urinary retention in both sexes.

Despite the fact that hyperprolactinemia-causing effect of tamsulosin has been shown in animal studies, there is not any reported human case of hyperprolactinemia related to tamsulosin in the English literature up to present. Therefore, we present this probably the first case of hyperprolactinemia due to tamsulosin.

\section{Case Presentation}

A 39-year-old female patient was referred to the endocrinology department of our hospital because of hyperprolactinemia. She had the complaint of galactorrhoea for a few days and her prolactin level was $>200 \mathrm{ng} / \mathrm{mL}$ (normal range: $2.8-29.2 \mathrm{ng} /$ $\mathrm{mL}$ ). The patient had been diagnosed with multiple sclerosis (MS) at the age of 21 and she has been treated with rituximab in the last 2 years. In addition, she had a traffic accident resulting in spinal cord injury and lumbar vertebral fractures two years ago. Vertebral osteomyelitis had occurred after the vertebral stabilisation operation, for this reason, the patient had undergone reoperation for vertebroplasty revision 6 weeks ago. After this operation, the loss of ability to urinate occurred and, thus, a urinary catheter was inserted. Tamsulosin therapy has been started to relieve complaints of urinary retention. She stated that galactorrhoea emerged in a few days after starting tamsulosin therapy.

No remarkable finding was detected on physical and neurological examination except mild hypoesthesia on both lower limbs. Hematological and biochemical tests were normal. The possibility of pregnancy or hypothyroidism was excluded by blood tests which are also summarized in Table 1. We also performed magnetic resonance imaging (MRI) to detect whether she had any lesion in the hypothalamopituitary area. Contrary to expected from the quite high level of prolactin, we could not find any lesion in these regions. However, numerous demyelinating plaques in various regions of the central nervous system, such as bilateral frontoparietal, parietooccipital, and temporal periventricular areas, were found on MRI (Figure 1).

After all this, tamsulosin was discontinued at the 7th day of admission because there was not another visible cause of hyperprolactinemia. As expected, galactorrhoea recovered in a few days. Likewise, the serum level of prolactin decreased
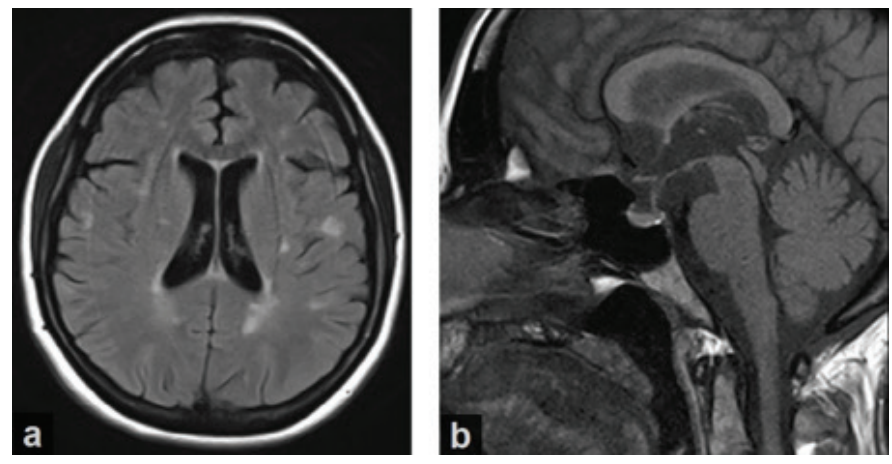

Figure 1. Brain magnetic resonance imaging of the patient: a) Demyelinating plaques on axial image; b)Sagittal section image of the pituitary gland and hypothalamic region

Table 1. Hormonal results of the patient

\begin{tabular}{lll}
\hline Test & Result & Reference range \\
\hline TSH & $0.91 \mu \mathrm{lU} / \mathrm{mL}$ & $0.27-4.5$ \\
\hline Free T3 & $2.92 \mathrm{pg} / \mathrm{mL}$ & $2-4.4$ \\
\hline Free T4 & $1.25 \mathrm{ng} / \mathrm{dL}$ & $0.93-1.71$ \\
\hline$\beta$-hCG & Negative & - \\
\hline Prolactin & $>200 \mathrm{ng} / \mathrm{mL}$ & $2.8-29.2^{*}$ \\
\hline Cortisol & $18 \mu \mathrm{g} / \mathrm{dL}$ & $4.6-22.8$ \\
\hline
\end{tabular}

TSH: Thyroid stimulating hormone, T3: Triiodothyronine, T4: Thyroxine, $\beta$ - hCG: Human chorionic gonadotropin hormone beta-subunit, ${ }^{*}$ In non-pregnant women 
dramatically (from $200 \mathrm{ng} / \mathrm{mL}$ to $5.18 \mathrm{ng} / \mathrm{mL}$ ). Urinary complaints of the patient were controlled with bethanechol, then, her urinary catheter was removed. Micturition was achieved with bethanechol therapy without significant post void residual urine.

\section{Discussion}

Tamsulosin is a selective alpha 1A-adrenoreceptor blocker. These receptors are primarily located in the human prostate, bladder base, bladder neck, and the prostatic urethra. Blockade of alpha 1A-adrenoreceptors brings about relaxation of the prostatic and urethral smooth muscles, thus decreasing bladder outlet resistance without affecting detrusor smooth muscle contractility. In fact, tamsulosin is used to treat benign prostate hyperplasia in men, however, its use might also be effective in women to relieve obstructive and irritative urinary symptoms via the mechanism mentioned above. In recent years, efficiency and safety of tamsulosin in women with lower urinary tract symptoms and voiding dysfunction have also been demonstrated $(3,4)$.

Tamsulosin has a weak D2-dopamine receptor blocking effect besides alpha-1-receptor blocking effect (5), and elevates blood prolactin level significantly in rats and mice. Even, hyperplasia of female rat mammary gland has been observed in 3-month and 12-month dietary toxicity studies of tamsulosin (6). However, hyperprolactinemia due to tamsulosin has not been reported in humans until now.

MS is an autoimmune neurologic disease that is characterised by demyelination of the white matter in the central nervous system. Some of previous studies have revealed a slightly elevated prolactin level in patients with MS than in healthy controls $(7,8)$. Indeed, the source of high prolactin levels among those patients is unclear, albeit observations suggest that it may be a part of a non-specific hypothalamic-pituitary axis dysregulation due to neurodegeneration and/or demyelination (9). On the other hand, some medications such as beta-interferon which is used in the treatment of MS might also elevate prolactin level (10). However, hyperprolactinemia related to rituximab has not been reported yet. Therefore, hyperprolactinemia in our case has seemed due to neither a lesion in the hypothalamic-pituitary region nor side-effects of a drug used to treat MS.

There was a potential cause such as MS that might have contributed to development of hyperprolactinemia in our case. Howbeit, it is expected that MS lead mildly and transiently elevated prolactin levels. In the present case, overt hyperprolactinemia with galactorrhoea manifested just after tamsulosin treatment. As mentioned before, she had also not any symptom related with hyperprolactinemia before starting treatment with tamsulosin. Furthermore, hyperprolactinemia resolved following the discontinuation of the drug.
Consequently, drug-induced hyperprolactinemia may occur with numerous medications. This is likely the first case of hyperprolactinemia due to tamsulosin which is an alpha-1 adrenergic receptor antagonist. We recommend that symptoms related to hyperprolactinemia, such as galactorrhoea, oligomenorrhea and amenorrhea, should be considered if this drug will be used in female patients.

\section{Ethics}

Informed Consent: The informed consent about the manuscript was taken from the patient.

Peer-review: Externally peer-reviewed.

\section{Authorship Contributions}

Concept: A.G., A.S., Design: A.G., Data Collection and/or Processing: M.T., Analysis and/or Interpretation: M.T., S.G., Literature Research: S.G., M.S., Writing: A.G.

Conflict of Interest: No conflict of interest was declared by the authors

Financial Disclosure: None.

\section{References}

1. Majumdar A, Mangal NS. Hyperprolactinemia. J Hum Reprod Sci 2013;6:168175.

2. Shibli-Rahhal A, Schlechte JA. Prolactinomas: Diagnosis and Management Edit: B Swearingen, BMK Biller. Diagnosis and Management of Pituitary Disorders. Humana Press 2008;125-140.

3. Kim S-0, Choi HS, Kwon D. The $\alpha 1$ Adrenoceptor Antagonist Tamsulosin for the Treatment of Voiding Symptoms Improves Nocturia and Sleep Quality in Women. Urol J 2014;11:1636-1641.

4. Minardi $D$, Pellegrinelli $F$, Conti A, Fontana $D$, Mattia M, Milanese $G$, Muzzonigro G. $\alpha 1$-Blockers for the treatment of recurrent urinary tract infections in women with dysfunctional voiding: A prospective randomized study. Int J Urol 2015;22:115-121.

5. Honda K, Miyata-Osawa A, Takenaka T. Alpha 1 - adrenoceptor subtype mediating contraction of smooth muscle in the lower urinary tract and prostate of rabbits. Naunyn Schmiedeberg's Arch Pharmacol 1985;330:1621.

6. Sakai T, Sakai H, Owen NV, Usher RW, Cherry LD, Brown GE, McGrath JP, van Lier RBL. Toxicity studies of YM617 (LY253351) in rats. The Clin Rep 1990;24:451-464.

7. Shafa MA, Vakilian A, Poorebrahimi A, Kahnali JA. Serum prolactin level in multiple sclerosis patients. J Res Med Sci 2006;11:325-328.

8. Moshirzadeh S, Ghareghozli K, Harandi AA, Pakdaman H. Serum prolactin level in patients with Relapsing-Remitting Multiple Sclerosis during relapse. J Clin Neurosci 2012;19:622-623.

9. Zhornitsky S, Yong VW, Weiss S, Metz LM. Prolactin in multiple sclerosis. Mult Scler 2013;19:15-23.

10. Then Bergh F, Kumpfel T, Yassouridis A, Lechner C, Holsboer F, Trenkwalder C. Acute and chronic neuroendocrine effects of interferon-beta 1a in multiple sclerosis. Clin Endocrinol 2007;66:295-303. 